AperTO - Archivio Istituzionale Open Access dell'Università di Torino

\title{
Italian Loan Words in the Inflexional Noun System of Modern German
}

\section{This is the author's manuscript}

Original Citation:

Availability:

This version is available http://hdl.handle.net/2318/127966

since

Terms of use:

Open Access

Anyone can freely access the full text of works made available as "Open Access". Works made available under a Creative Commons license can be used according to the terms and conditions of said license. Use of all other works requires consent of the right holder (author or publisher) if not exempted from copyright protection by the applicable law. 


\section{Italian Loan Words in the Inflexional Noun System of Modern German*}

\section{Livio Gaeta}

\section{Abstract}

Italian loan words constitute a broad and homogeneous subset within the German lexicon. On the basis of Natural Morphology, they will be used to provide a coherent description of the much debated German inflexional noun system. The notion of Paradigm and of dominant Paradigm Structure Condition are in this perspective very useful for the study of the integration of foreign words into the German system. Finally, the results of this analysis will be compared with the recent proposals of Carstairs $(1986,1987)$ concerning the concepts of Macroclass and of the Paradigm Economy Principle. These notions are inadequate, if taken as a rather mechanical and unrestricted tool to simplify the inner complexity of the inflexional system.

\section{Introduction}

Many studies have been devoted to the thorny problem of the German inflexional noun system (cf. among others, Augst 1979 and Korte 1986). Nevertheless, the question is still unclear, because of the great number of paradigms and ways of marking the plural. Up to 16 (or more, cf. Jørgensen 1980 and the literature quoted there) inflexional classes (=ICs) have been singled out, and it may still be objected that not all possible inflexional types have been taken into account.

Table 1 lists all $16 \mathrm{ICs}$, giving only the case and number where they usually differ.

Although the major ICs are all represented here, difficulties arise when one tries to formulate some generalizations or rules that would predict, for example for a foreign student of German, which IC occurs with which word class. In other words, this representation of the inflexional noun system of German is static: it gives a fairly systematic picture of the occurring types, but it does not enable the speaker (or the learner) to understand which word belongs to a certain class. In order to overcome the 'staticness' of this representation, it might be useful to state explicitly which ICs are actually productive. There are two phenomena that 
Table 1

\begin{tabular}{|c|c|c|c|c|c|c|c|c|c|}
\hline & I & II & III & IV & V & VI & VII & VIII & IX \\
\hline & Tag & Ziegel & Gast & Hand & Apfel & Mutter & Mann & Uhu & Mutti \\
\hline & 'day' & 'goat' & 'guest' & 'hand' & 'apple' & 'mother' & 'man' & 'owl' & 'mum' \\
\hline Gen. Sg. & $-\mathrm{s}$ & $-s$ & $-\mathrm{s}$ & $-\varnothing$ & $-\mathrm{s}$ & $-\varnothing$ & $-\mathrm{s}$ & -s & $-\varnothing$ \\
\hline \multirow[t]{4}{*}{ Nom.Pl. } & $-\mathrm{e}$ & $-\varnothing$ & -e & -e & $\because \varnothing$ & $\because \varnothing$ & -er & $-\mathrm{s}$ & $-\mathrm{s}$ \\
\hline & $\mathrm{X}$ & XI & XII & XIII & XIV & $\mathrm{XV}$ & XVI & & \\
\hline & Bär & Rose & Dorn & Name & Museum & Firma & Cello & & \\
\hline & 'bear' & 'rose' & 'thorn' & 'name' & 'museum' & 'firm' & 'cello' & & \\
\hline Gen.Sg. & $-n$ & $-\varnothing$ & $-s$ & -ns & $-s$ & $-\varnothing$ & -s & & \\
\hline Nom.PI. & $-n$ & $-n$ & $-n$ & $-n$ & truncation $-\mathrm{n}$ & trunc. $\mathrm{n}$ & trunc. $-\mathrm{i}$ & & \\
\hline
\end{tabular}

usually are considered a manifestation of productivity and which have to be captured by a 'dynamically' organized morphological system: changes of IC ('metaplasms') and the inflexion of new words, whether of true new coinages or of loan words. The topic of this paper will be the subset of the German lexicon constituted by loan words from Italian. The Italian loan words constitute a broad and homogeneous subset within the German lexicon: as a rule, Italian loan words belong to restricted semantic fields, like the specific terminology for music or cuisine or the economy. ${ }^{1}$ But there are also very common Italian loan words that occur in the German Alltag, despite their foreign form: e.g. Espresso 'espresso', Firma 'firm', Konto 'account', Marone 'roast chestnut', Villa 'villa', etc. I will proceed as follows: after a very short exposition of a more adequate theory for the description of the German inflexional noun system I will introduce the Italian loan words and try to show how they can contribute to the solution of a few of the questions that remain open in the theory. Finally, I will compare the results of my analysis with the recent proposals of Carstairs concerning the concepts of macroclass and the Paradigm Economy Principle.

\section{Wurzel's Model of Inflexional Morphology}

The morphological model elaborated by Wurzel $(1984,1987 a)$ interprets the inflexional rules of a language as a set of implications deriving from more general system-defining structural properties that characterize the specific inflexional system of a language. For the sake of brevity, it is enough to say here that a very important system-defining structural property of the German inflexional noun system is the occurrence of word-based inflexion and additive morphological markers, while Italian, as is known, shows the other type, with stem-based inflexion and substitutive markers ${ }^{2}$ (cf. Ger. Tag/Tag-e vs. It. giorn-o/giorn-i) The German inflexional noun system can be captured by the following set of paradigm structure conditions (PSC): ${ }^{3}$
$\operatorname{PSC}(\mathrm{A}) \quad[+\mathrm{N},-\mathrm{V}] \rightarrow[-(\mathrm{n}) /$ dat.pl., $-\varnothing /$ gen.-acc.pl. $]$

PSC(B) $\quad[\{-\varnothing ;-(\mathrm{e}) \mathrm{s}\} /$ gen.sing. $] \rightarrow[-\varnothing /$ dat.-acc.sing. $]$

$\mathrm{PSC}(\mathrm{C}) \quad[\{-(\mathrm{e}) \mathrm{n} ;-\mathrm{ns}\} /$ gen.sing. $] \rightarrow[-(\mathrm{e}) \mathrm{n} /$ dat.-acc.sing. $]$

These are general implications, regarding the structure of paradigms. The following PSCs build up the most productive inflexional paradigms (or macroclasses):
$\operatorname{PSC}(\mathrm{I}) \quad[+$ fem. $] \rightarrow[-\varnothing /$ gen. sing., $-(\mathrm{e}) \mathrm{n} /$ plur. $]$ die Biene 'bee' $\rightarrow$ der Biene/die Bienen
PSC(II) $\quad$ [-fem.] $\rightarrow$ [-(e)s/gen.sing., -e/plur.] der Tag $\rightarrow$ des Tages/die Tage

Within these two macroclasses the more restricted ICs are set up by the following PSCs:

PSC(IIa) [+masc., -/e\#/, +animated] $\rightarrow$ [-(e)n/gen.sing., -(e)n/plur.] der Experte 'expert' $\rightarrow$ des Experten/die Experten

PSC(IIb) [unreduced vowel\#] $\rightarrow$ [-s/plur.] der Uhu 'eagle-owl' $\rightarrow$ die Uhus

PSC(IIc) [/ge_e\#/; -/el/\#; -/er/\#; -/en/\#; -/lein/\#] $\rightarrow$ [- Ø/plur.] der Koffer 'suitcase' $\rightarrow$ die Koffer

Within the other macroclass (I), more restricted PSCs must be set up:

PSC(Ia) [unreduced vowel\#] $\rightarrow$ [-s/plur.] die Oma 'grandma' $\rightarrow$ die Omas

$\operatorname{PSC}(\mathrm{Ib}) \quad$ [non-front vowel, relationship, /-er/\# $] \rightarrow["-\varnothing /$ plur. $]$ die Tochter 'daughter' $\rightarrow$ die Töchter

PSC(Ic) $\quad[-/+$ nis\#/; -/+sal\#/] $\rightarrow$ [-e/plur. $]$ die Kenntnis 'knowledge' $\rightarrow$ die Kenntnisse

The other inflexional types occurring in the system, but which are not captured by these PSCs (namely the ICs III-V, VII, XII-XIII and the three ICs XIV-XVI with truncation in Table 1) have to be considered as non-productive. Their occurrence is fairly restricted within the German lexicon; they can better be represented as lexically marked and constituting complementary unstable classes (cf. Wurzel 1984, Bittner 1988, 1993).

Two remarks need to be added to this rather sketchy representation:

1) The more general PSCs (A), (B) and (C) are statements about the inflexional behaviour of substantives within their own ICs. The other PSCs on the other hand build up ICs relating them to extramorphological properties;

2) The difference between the mentioned above macroclasses (PSC (I) and (II)) and the other ICs is twofold: the latter are more restricted, in the specific 
sense that more (extramorphological) properties are involved in their definition. Moreover, the relation between the two macroclasses and the other ICs is in terms of default-rules. As Bittner observes, "weisen Sprachwandelprozesse und Spracherwerbsdaten darauf hin, daß diese Klassen das produktive, normalerweise zu erwartende Flexionsverhalten der deutschen Substantive repräsentieren. Man kann sagen, es ist gegenwärtig der Default-Fall" (Bittner 1993:78-79).

\section{Inflexional Class and Paradigm}

Nevertheless, in Wurzel's theory the concept of the (macro)paradigm plays a very limited role. Indeed, he distinguishes between an IC and a paradigm:

"Indem die Paradigmenstrukturbedingungen die implikativen Relationen zwischen den Flexionsformen der Wörter konstatieren, erfassen sie nicht nur die Zusammengehörigkeit der Formen zu einem einheitlichen Paradigma. Sie fixieren zugleich den unterschiedlichen Statu der einzelnen Formen des Paradigmas: Es wird unterschieden zwischen den vom Sprecher zusammen mit der lexikalischen Grundform eines Wortes zu erlernenden 'Kennformen' (...) und den sich daraus ergebenden übrigen Formen des Paradigmas, eben zwischen implizierenden und implizierten Formen. Damit wird dem Faktum Rechnung getragen, daß ein Flexionsparadigma mehr ist als die Summe seiner Formen, daß es eine spezifischere innere Struktur ist." (Wurzel 1988:269).

A paradigm is thus the result of the (more or less) complex organization of PSCs, i.e. it is constituted by the latter. Nevertheless, once stated that the single forms occupy a different place within the paradigm, it is not clear what role the paradigm (as an entity that is "more than the sum of its parts") plays in the organization of the inflexional system. As Bittner \& Bittner observe, it seems that for Wurzel ICs are only a disturbing factor, that increases the complexity of the morphological system without empirical utility. In their words, ICs

"repräsentieren als solche lediglich die zu einem konkreten Zeitpunkt gegebene, historisch ererbte formal-morphologische Struktur eines Flexionssystems, nicht aber ein 'Organisationsprinzip' im Sinne eines bestimmten nichtformalen Kriterien folgenden innersystematischen Strukturzusammenhangs, der Aufbau und Veränderung des Flexionssystems determiniert" (Bittner \& Bittner 1990:24)

Thus, the inflexional system should be thought of as structured according to well extramorphologically anchored paradigms, in order to function as a central "organization principle" retrieved by the speakers. The macroclasses can therefore be understood as built up by dominant PSCs such as PSC (I) and (II): the hierarchical organization of the inflexional system allows the markedness of the inflexional paradigm of single words to be measured. Moreover, predictions can be made regarding both the possible development of the system and the historical tendencies 'marked' ICs undergo. We will see below how the scale of markedness is relevant for Italian loan words.

Table 2
\begin{tabular}{|l|l|l|}
\hline & IC & PSC \\
\hline der Golf' 'gulf' & $\mathrm{I}$ & $(0, \mathrm{~A}, \mathrm{II})$ \\
\hline der Kanal 'canal' & $\mathrm{III}$ & die Kanäle \\
\hline der Kreditor 'creditor' & $\mathrm{XII}$ & die Kreditoren \\
\hline der Tarock 'tarot card' & VIII? & die Tarocks \\
\hline der Torrente 'torrent' & $\mathrm{XII}$ & die Torrenten \\
\hline der Virtuose 'virtuoso' & $\mathrm{X}$ & $(0, \mathrm{~B}, \mathrm{IIa})$ \\
\hline der Zucchino 'zucchini' & $\mathrm{XVI}$ & die Zucchini \\
\hline der Saldo 'sale' & $\mathrm{XIV}$ & die Salden \\
\hline das Ghetto 'ghetto' & $\mathrm{VIII}$ & $(0, \mathrm{~A}, \mathrm{IIb})$ \\
\hline die Sardelle 'sardelle' & $\mathrm{XI}$ & $(0, \mathrm{~A}, \mathrm{I})$ \\
\hline die Ottava 'octave' & $\mathrm{XVI?}$ & die Ottave \\
\hline die Villa 'villa' & $\mathrm{XV}$ & die Villen \\
\hline die Mafia 'Mafia' & $\mathrm{IX}$ & $(0, \mathrm{~A}, \mathrm{Ia})$ \\
\hline
\end{tabular}

\section{Italian Loan Words}

Let us now take a look at the set of Italian loan words contained in the latest edition of DUDEN: FREMDWÖRTERBUCH published in 1991 and enlarged by more than 1000 new words. I will not give very much importance here to the distinction between loan and foreign words assumed in specific works on language interference, ${ }^{6}$ since it is clear that a great number of loan words dealt with here are not completely (or not at all) integrated into the German language structures. As a matter of fact, the Italian foreign words ${ }^{7}$ present two major difficulties for German speakers, because they end mostly in vowels and make use of stem-based inflexion and substitutive markers (s. above). They usually undergo processes of integration (Eindeutschung) in order to eliminate the properties that are problematical for German ears. ${ }^{8}$ We find degrees of variation, going from simple adoption and use, as if they were 'quotation forms' ${ }^{9}$ to complete integration into the German lexicon. Table 2 above gives the Italian loan words together with the IC and possibly the PSC they are subject to.

Italian loan words seem to confirm the predictions made on the basis of PSCs: apart from those loan words that follow a foreign IC, i.e. IC XVI in Table 1, the other inflexional types reported in Table 2 that are not related to a PSC are very marginal in the corpus. Moreover, some ICs in Table 1 are not represented: II, IV, V-VII, XIII.

The loan words vary both with respect to the range of morphological integration, in some cases showing Italian morphemes (as in the IC XVI in Table 1), cf Zucchini, Ottave, and with respect to the range of phonological integration, where some loanwords no longer display ‘foreign' features, cf. Golf, Tarock. In 
my view, the range of morphological integration may be measured in relation to the loan words' membership of one of the 'major' ICs, i.e. an IC set up by a dominant PSC. We can also imagine the morphological integration as a continuum, in which different phases of integration are singled out: on this view morphological integration is seen as decrease of MARKEDNESS. The degree of markedness is established on the basis of the number of system-dependent structural properties that remain violated in the loan word (cf. Poitou 1987). Moreover, I also consider the markedness of loan words that do not fall under a PSC, even though provided with the necessary (extramorphological) properties: in the latter case, it is the PSC which is 'violated'.

In the following table, the types of morphological integration into the German morphological system are illustrated in relation to the degree of markedness (M) within the system:

Table 3
\begin{tabular}{|l|l|l|}
\hline M-2 & M-1 & M-0 \\
\hline Celli & Konten & Diskonte \\
\hline & Tarocks & Gettos \\
\hline Karabinieri & Torrenten & Virtuosen \\
\hline & Kreditoren & (fem.) Putten \\
\hline Ottave & Villen & Sardellen \\
\hline & Mafias & \\
\hline
\end{tabular}

The M-2 column lists forms that do not show any integration and maintain their original inflexional type; at an intermediate stage (M-1), there are loans that do not fall under the influence of a PSC or that have a 'spurious'10 inflexion, i.e. where the loans acquire a German plural morpheme, but "unter Bedingungen, die nicht für die Erbwörter gelten (Poitou 1987:109)". Moreover, there is a group of words (cf. Konten/Kontos/Konti 'account', Saldo/Saldos/Saldi, etc.), where the plural varies from the $e n$-class, or the foreign $i$-class, to the $s$-class. Finally, the less marked forms are given under M-0.

The reduction of markedness seems to take place along two paths:

a) for non-feminine nouns through the loss of the final vowel and for feminine nouns through the reduction of the final vowel to $-e$;

b) through the assumption of an unmarked plural form, i.e. one subject to a PSC.

The last step, i.e. the assumption of a plural form that is subject to a dominant PSC, is crucial in order to assign M-0 to loan words that are in other respects (for example phonologically) integrated. In Table 3, for example, the loan word Kreditor is counted as M-1 despite its phonological integration, because it does not correspond to PSC (II) - type Tag/Tage - nor to PSC (IIa) - type Experte/Experten -, since the genitive singular form is Kreditors. The prediction that can be made on the basis of the PSCs is that this morphological type of integration will be very rare. In fact, only three other words that belong to this IC are present in my corpus, namely Intarsiator 'inlayer', Miniator 'miniaturist', and Stukkator 'stucco decorator'. The same is true for the type Tarock/Tarocks, in comparison with Diskont/Diskonte 'discount'.

Another way to reduce markedness, not accounted for by Poitou (1987), is exemplified by the type Putte 'putto' in Table 3. For this word the form with 'spurious' inflexion is also attested, i.e. der Putto/Putten (from It. - masculine! - putto). Here a reanalysis has taken place, in which from the plural form which has the German plural marker typical for feminine nouns (cf. PSC (I)), the phonological form in the singular is simplified and the word therefore assumes feminine gender. By doing so, the violation of the system-defining structural property of word-based inflexion is suppressed, and the markedness decreases.

To sum up, the process of integration of Italian (and to a large extent Latin, cf. Poitou 1987) loan words displays this set of alternatives:

a) in the case of Diskont/-e, Sardelle/- $n$ markedness is suppressed in every respect, whether phonological (elimination of unreduced final vowels) or morphological (integration into an IC set up by a PSC);

b) at a different level, integrated forms like Kont-en and Firm-en do not present foreign unreduced final syllables, but in the singular they show violation of the property of word-based inflexion;

c) along with the reduction of final vowels, other extramorphological properties can 'push' the word under the influence of another PSC. This is the case with words like Assassine 'murder', Komparse 'walk-on part', Sbirre 'cop', Virtuose, etc., provided with the properties [+masc., -/e\#/, +animated], that are 'attracted' by the PSC (IIa) - type Experte. Otherwise, the form is restructured and changes its extramorphological property of gender, like die Skizze 'sketch' from an originary It. schizzo, or Arpeggione 'arpeggione' Melone 'melon', Oboe 'oboe', Putte, etc.

\section{The s-Plural}

Among the PSCs given in $\S 2$, those regarding the ICs characterized by the presence of $-s$-plural are identical:

PSC(Ia) [unreduced vowel\#] $\rightarrow[$-s/plur. $]$

PSC(IIb) [unreduced vowel\#] $\rightarrow$ [-s/plur. $]$

It could appear superfluous at first sight to provide two different PSCs in order to represent identical morphological behaviour. It might be more adequate to intro- 
duce a new PSC such as the following, where the gender as an extramorphological feature does not play any role at all:11

$$
\text { PSC(III) [unreduced vowel\#] } \rightarrow \text { [-s/plur.] }
$$

Moreover, if we compare this integration type with the so called spurious type i.e. ICs XIV and XV in Table 1, it turns up that both tendencies towards integration either into the spurious IC or into the $s$-plural class seem to point to different periods of German linguistic history rather than to be in conflict (cf. Öhmann 1924, Rettig 1972). After the $s$-plural became productive, it was used at first as an 'emergency' plural, still peripherical,12 but offering considerable possibilities for expansion. Nowadays, the $s$-plural is used regularly also with proper names (cf. die Grimm-s) and abbreviations (e.g. die PKWs). However, some differences still remain. If we take a look at Table 4, we will become aware of the inadequacy of PSC(III) in comparison with the different behaviour of non-feminine and feminine Italian loan words ending in a full vowel:

\begin{tabular}{|c|c|c|}
\hline & $\mathrm{M} / \mathrm{N}$ & $F$ \\
\hline$s$-inflexion & $72 / 31.3 \%$ & $32 / 22.1 \%$ \\
\hline stem inflexion & $45 / 19.6 \%$ & $91 / 62.7 \%$ \\
\hline double forms & $113 / 49.1 \%$ & $22 / 15.2 \%$ \\
\hline Totals & $230 / 100.0 \%$ & $145 / 100.0 \%$ \\
\hline
\end{tabular}

In this table the first number refers to lexical items, whereas the percentage is counted on the basis of the total number of items found for that word group. It should be remarked that the high number of double forms among masculine and neuter nouns in most cases (93\%) regards variation between the type with $s$-plural and the type with 'Italian' plural markers, whereas feminine nouns fluctuate only between the $s$-plural and the 'spurious' inflexion type.

Among the stem-inflected words, the distribution of the type Konto/Konti (so called 'Italian' type) and of the type Konto/Konten ('spurious' type) is reported in Table 5.

Tables 4 and 5 show that whereas non-feminine loan words in -o in most cases fall under PSC(IIb), feminine loan words in $-a$ display en-plural, even though in this way the system-defining structural property of word-based inflexion is violated. ${ }^{13}$ In order to account for this asymmetry between PSC(Ia) and PSC(IIb), I have inserted the type with $s$-plural into different levels of markedness in Table 3 above.
Table 5

\begin{tabular}{|l|c|c|}
\hline & $\mathrm{M} / \mathrm{N}$ & $\mathrm{F}$ \\
\hline 'Italian' type & $41 / 91.1 \%$ & $14 / 15.4 \%$ \\
\hline 'spurious' type & $4 / 8.9 \%$ & $77 / 84.6 \%$ \\
\hline Totals & $45 / 100.0 \%$ & $91 / 100.0 \%$ \\
\hline
\end{tabular}

Bittner seems to be aware of the ambiguity hidden in this formulation of both PSCs when she states that "eingeschränkt wird der Geltungsbereich von PSB(B) [= PSC(Ia), LG] durch Feminina auf halblangen Vokal, die im Plural mit Stammflexion en-Plural annehmen (Bittner 1988:45)". In fact, she introduces a new and more specific PSC, which may be represented as follows:

$$
\text { PSC (Ia)i [+fem., /__ / stem }] \rightarrow \text { [sing.: }-\varnothing \text {, plur.: - en] }
$$$$
\text { die Villa } \rightarrow \text { die Villen }
$$

Nevertheless, she maintains that "der überwiegende Teil der einschlägigen Substantiven zeigt zugleich Formen mit s-Plural, die sich tendenziell durchsetzen, vgl. Lig-en/Liga-s, Firm-en/Firma-s, Vill-en/Villa-s (ibidem)". Besides the fact that for these forms DUDEN does not display double forms with $s$-plural, it must be stressed that PSC(Ia)i feeds the dominant PSC(I) - type Biene/Bienen and that for this reason is preferred for the integration of loan words. In practice, PSC(Ia)i stresses the prominence of PSC(I) as a dominant PSC (s. above §3). On the contrary, within the other macroclass - type Tag/Tage - , the stem-inflected words do not indirectly feed a dominant PSC, since $n$-inflection is discarded as an alternative, apart for those nouns endowed with the specific properties $[+$ masc., -/e\#/, +animated], like der Experte.

The structural difference between the two macroclasses becomes evident in the different strength of their markers. Among the morphological markers used to form the plural, it has been observed that -en is iconically (cf. Mayerthaler 1981) and perceptively (cf. Köpcke 1988) strong. Köpcke (1988) introduces the notion of 'cue validity', i.e. "the frequency with which a particular feature occurs in the categories which contrast with the target category". As a plural marker -en has a high gradient of cue validity because

1) there is a high number of words that form the plural with this marker, while the number of singular words ending in -en is very limited;

2 ) as a plural marker -en occurs almost exclusively in the plural paradigm of nouns (the only type that makes exception is Bär, set up by PSC (B) and (II)a; ${ }^{14}$

3 ) the cognitive availability of -en as a plural marker is also strengthened by the association with plurality in the finite verb paradigm, specifically $1 \mathrm{st}$ and $3 \mathrm{rd}$ persons: die Studenten studieren 'the students learn'.15 
There are, in my opinion, three other reasons that strengthen the appropriateness of -en as a plural marker, in this case for feminine Italian loan words:

4) this marker is tied to the very strong PSC (I): its strength depends both on its occurrence with a large number of lexical items ${ }^{16}$ and on the absence of a high number of complementary ICs (cf. Wurzel 1984:122ff.);

5 ) this nasal plural is displayed in most cases by feminine words ending in a (reduced) vowel, i.e. $[-\mathrm{V}]_{\mathrm{N}}+[-\mathrm{n}]_{\mathrm{PLUR}}$, which correspond also to the typical phonological structure of Italian loan words;

6) finally, in the plural paradigm with -en all forms are identical as within the $s$-plural paradigm.

Moreover, Bittner, in her analysis, fails to take into account the fact that the en-plural 'normalizes' the phonological form of the word through the removal of a final syllable containing an unreduced vowel, 17 while at the same time 'pushing' the foreign word under the influence of a dominant PSC. On the one hand the decrease of phonological markedness (the opposite of what Bittner says: "Systemangemessenes Flexionsverhalten mit en-Plural wird bei diesen Substantiven phonologisch disfavoriert (1988:44)") and on the other the strength of a dominant PSC allow the violation of the system-defining structural property of word-based inflexion.

\section{Macroclasses and Carstairs' PEP}

Recently, Carstairs $(1986,1987)$ has suggested relating the notion of macroclass to his Paradigm Economy Principle:

"the number of macroparadigms for $\mathrm{N}$ is no greater than the number of distinct 'rival' macroinflexions available for that bundle which is most generously endowed with such rival realisations" (Carstairs 1987:51).

Morphological changes among ICs would have to take place in order to rescue this principle. PEP has undergone several criticisms, ${ }^{18}$ but one point needs to be stressed: the explanation power of PEP is limited, since "aufgrund der Dehnbarkeit des Ähnlichkeitsbegriffes alle möglichen Konstruktionen von 'macroparadigms' zuläßt und zum anderen nicht die hierarchische Zusammenhänge zwischen den außermorphologischen Eigenschaften berücksichtigt (Bittner \& Bittner 1990:34-5)".

For example, in the case of German substantives such as Name, which tend to undergo analogical restructuring of the nominative form on the model of IC II in Table 1 above, i.e. Name > Namen, Carstairs observes that "superficially, defection to type II [=PSC(II) Tag/Tage, LG] and defection to type X [=PSC(IIa) Experte/Experte, LG] both involve a change in only one form (the N.Sg. and G.Sg. respectively), and so would seem on a priori grounds about equally likely, with the latter perhaps marginally preferred because it involves a change in a more 'marked' form (the Genitive) rather than a less 'marked' one (the Nominative)" (Carstairs 1987:248).

However, Carstairs in his explanation does not mention the fact that for a noun to be included in the IC set up by PSC (IIa) a specific extramorphological property is required, namely animatedness. Otherwise, metaplasms would enrich the dominant macroclass, set up by PSC(II). Therefore, the morphological change supposed by him to be likely "on a priori grounds", namely (cf. Carstairs 1987:249):

\begin{tabular}{|c|c|c|}
\hline Same & & Same \\
\hline Samen-s & $\rightarrow$ & Same-n \\
\hline $\begin{array}{l}\text { Samen } \\
\text { etc. }\end{array}$ & & $\begin{array}{l}\text { Same-n } \\
\text { etc. }\end{array}$ \\
\hline
\end{tabular}

is false, since the extramorphological property of animatedness is not contained in the noun Same 'seed'. In fact, it does not take place. ${ }^{19}$

Another example that speaks against the explanation power of PEP is provided by Italian loan words ending in an unreduced vowel. Within Carstairs' model, they are assigned to two different paradigms, ascribable to the same macroclass on the basis of the principle that "two or more distinct inflexion classes with similar paradigms belong to one macroclass if all the inflexional differences between them can be predicted on the basis of (a) differences in the phonological shape of the stems or (b) lexically determined syntactic or semantic differences (Carstairs 1986:4, italics mine)". Crucially, the ICs VIII and IX in Table 1, containing as subclasses XV and XVI, were assigned to an independent macroclass taking $s$-plural. Besides the arbitrariness of the criteria according to which the macroclasses are set up, already observed by Bittner \& Bittner (s. above), Carstairs fails to take into account the structural differences between the macroclasses of feminine and of non-feminine nouns, a difference which leads to the phenomena seen above in Tables 4 and 5 . As shown above, the difference in the integration of feminine and non-feminine loan words finds an explanation if attention is paid to the other ICs. Because of PSC(I), the greater stability of the enplural in the case of feminine nouns is structurally motivated, whereas for nonfeminine nouns it remains strongly marked (and very rare).

\section{Conclusion}

The representation of the German inflexional system through extramorphologically based PSCs seems to be very adequate as a way of accounting for the integration processes which Italian loan words undergo. Also the apparent counterexample constituted by feminine loan words finds an explanation if the facts are 
shown in their true light. It is the notion of inflexional macroclass that can explain possible violations of system-defining structural properties. Note that the violated structural property of word-based inflexion is not valid throughout the German inflexion system: in fact, in verbal paradigms stem-based inflexion does occur (e.g. er sag-t/sie sag-en). On the other hand, Carstairs' notion of macroclass and his PEP cause some difficulty, because they cannot explain why two words belonging to the same macroclass in his model behave in different ways.

\section{Address of the Author}

\section{Livio Gaeta}

III University of Rome \&

Scuola Normale Superiore

Piazza dei Cavalieri 7

I-56100 Pisa (Italy)

e-mail: gaeta@sab.sns.it

\section{Notes}

* Many thanks are devoted to P. Tucker for improving my English.

Cf. Kühebacher (1968), Grassi (1987), Basile (1991) and Gaeta (in press).

2 For an extensive description and discussion of these concepts, cf. Mayerthaler (1981), Wurzel (1984, especially 93ff.), and Wurzel (1987a). An apparent exception to this property is constituted by the inflexional classes XIV-XVI in Table 1, containing (mostly Italian) loan words. There are also scholars like Harnisch (1990), who assumes that German has indeed the system-defining property of stem-based inflexion throughout the morphological system. We will see below that this position is not empirically supported.

3 For the setting of PSCs in German, s. furthermore Bittner (1988) and (1993).

4 There is also the form die Golfs, which has the meaning of a particular kind of car and cannot be taken as an Italian loan: the $s$-plural may be motivated either by the recent acquisition of this word into the German lexicon or by the semantic proximity with the hyperonymon AutoAutos.

5 As for the French loan words (cf. Volland 1986:135), plural forms with umlaut are very rare: in my corpus there are only three other instances: Baß, Contratenor and Tenor. This speaks clearly in favour of the non-productivity of this inflexional type in contemporary German. Cf. for a discussion Korte (1986) and Wurzel (1987b).

6 Cf., among others, Tesch (1978), Gusmani (1981) and, especially, Munske (1983).

7 As 'working' definition, we can say that foreign words are words of foreign origin that in a As 'working' definition, we can say that foreign words are words of foreign origin that in
synchronic analysis display foreign features in their formal structure, cf. Köpcke (1993:143).

8 This is the reason why it is misleading to assume stem-based inflexion as a system-defining structural property of German, as is done by Harnisch (1990): if it were so, why should Italian loan words undergo processes of integration in order to give up the type with truncation rule?

9 The expression is borrowed from Poitou (1987). He also refers to such extreme cases as where a word remains uninflected or "wird wie ein Zitat flektiert (Poitou 1987:94)"; in this case the word is stricto sensu transferred and loses its morphological identity.

10 Rettig (1972) attributes the emergence of this 'spurious' inflexion type to the influence of grammarians, among the most representative of whom was J. Adelung (1732-1806). Their intention was to avoid 'barbarous' forms, i.e. forms that take inflexional markers twice, the native and the German (s. for example the form, present in my corpus, die Azzurris). To avoid these superfluous 'baroque' forms, they prescribed the use of loan stems with appropriate German markers.

11 There are already scholars, who assume that the $s$-plural is the only productive one in contemporary German: cf. Bornschein \& Butt (1987) and the kind of analysis performed by Clahsen et al. (1992). It should be noted that under this assumption the gender as an inflexion feature (Flexionsmerkna (Flexionsmerkmal) becomes 'weaker', since it remains relevant just for distinguishing be-

tween fem (1969:96): "Ich hine in case inlexion (also weak in German, c. Wurzel 198\%).

12 Cf. Werner (1969:96): "Ich habe außerdem — wenn auch nach langem Zögern — das Plural-s in dieses Schema aufgenommen: (...) So wie die Wörter auf $-\mathrm{a},-\mathrm{i},-\mathrm{o},-\mathrm{u}$ erst aus der Peripherie ins Zentralsystem hereingekommen sind (...), so ist auch das Plural-s erst seit einiger Zei ein Teil des Zentralbereichs geworden". On the same topic twenty years later, cf. Bornschein \& Butt (1987:138): "Anscheinend hat sich der s-Plural schon zu dieser Zeit recht gut in der deutschen Hochsprache etabliert, zumindest als 'Notplural' für alle Fälle, in denen eine andere Pluralkennzeichnung nicht möglich ist oder unpassend erscheint. Allerdings läßt sich das Unbehagen, welches insbesondere gebildete Sprecher dem s-Plural gegenüber empfunden hat mögen, noch gut anhand heute unüblich gewordener Pluralbildungen wie Uhue, Reliefe, Kartone, Pendanten und Portraite erkennen".

13 Cf. also the tables provided by Köpcke (1993:129-32).

14 Selecting the relevant contrast set of forms for determining cue validity may be problematical. Köpcke takes the narrow position that only forms within the same morphological paradigm are relevant. For example, the high frequency of -en as marker for the weak declension of adjectives could theoretically lower the cue validity of $-e n$ as a plural marker. But case marking of weak adjectives is always contextually disambiguated by a preceding article and a following noun and is thus at least plausibly irrelevant to the contrast with -en as a plural marker (cf. Köpcke 1988).

15 Cf. cases where a verbal plural marker has been extended to noun morphology: e.g. the extension of -en to feminine plurals in the Northern Italian dialect spoken in the Mesolcina valley la vaken 'the cows', cf. Rohlfs (1969), §371a. I thank for this suggestion an anonymous reviewer of the article.

16 Bittner (1993) counts about 80\% feminine nouns displaying this type of plural.

17 Cf. Köpcke (1993:133): "Relativ ungewöhnlich klingende nominale Einträge im Singular werden durch die Vokalsubstitution zu hochgradig natürlich klingenden Pluralformen transformiert".

18 Cf. Nyman (1987) and Klausenburger (1989)

19 Cf, also Wurzel (1989:224).

\section{Bibliography}

Augst, Gerhard. 1979. "Neuere Forschungen zur Substantivflexion." Zeitschrift für germanistische Linguistik 7, 220-32.

Bassarak, Armin et al. (eds.). Wurzel(n) der Natürlichkeit. Linguistische Studien 208, Reihe A. Zentralinstitut für Sprachwissenschaft. Berlin: Akademie der Wissenschaften der DDR.

Basile, Grazia. 1991. "Gli italianismi nel lessico specialistico della lingua tedesca." In: Luciano Coveri (ed.). L'Italiano allo specchio: aspetti dell'italianismo recente. Torino: Rosenberg \& Sellier, 33-46.

Bittner, Dagmar. 1988 "Motivationsstrukturen im Flexionsverhalten der neuhochdeutschen Substantive - Vorschlag eines Modells." In: Wolfgang U. Wurzel (ed.). Studien zur Morphologie und Phonologie III. Linguistische Studien 188, Reihe A. Zentralinstitut für Sprachwissenschaft. Berlin: Akademie der Wissenschaften der DDR, 36-51.

Bittner, Dagmar. 1993. "Die außermorphologische Struktur von Flexionssystemen oder 'Was is eigentlich Paradigmenökonomie?"” In: Wolfgang U. Dressler \& Livia Tonelli (eds.). Natural Phonology: Perspectives for the Nineties. Padova: Unipress, 75-88. 
Bittner, Dagmar \& Andreas Bittner. 1990 “Sind Flexionsklassen nur morphologische Klassen?" In Bassarak et al. (eds.)., 17-36.

Bornschein, Matthias \& Matthias Butt. 1987. "Zum Status des s-Plurals im gegenwärtigen Deutsch.” In: Werner Abraham \& Ritva Århammar (eds.). Linguistik in Deutschland. Akten des 21. Linguistischen Kolloquiums. Tübingen: Niemeyer, 135-153.

Carstairs, Andrew. 1986. "Macroclasses and Paradigm Economy in German Nouns." In: Zeitschrift für Phonetik, Sprachwissenschaft und Kommunikationsforschung 39, 3-11.

Carstairs, Andrew. 1987. Allomorphy in Inflexion. Croom Helm Linguistic Series: London, New York, Sydney.

Clahsen, Harald, Monika Rothweiler, Andreas Woelst \& Gary F. Marcus. 1992 "Regular and Irregular Inflexion in the Acquisition of German Noun Plurals." Cognition 45.3, 225-255.

DUDEN: FREMDWÖRTERBUCH. Der Duden in 10 Bänden, Vol. 5. 4th edition. 1991. Mannheim: Dudenverlag.

Gaeta, Livio. In press. "Italianismi in tedesco: per una dinamica dei processi di integrazione." In Luciano Agostiniani, Maria Giovanna Arcamone, Onofrio Carruba, Fiorella Imparati \& Riccardo Rizza (eds.). Miscellanea in ricordo di Adriana Q. Moreschini. Pisa: Giardini.

Grassi, Corrado. 1987. "La componente italiana nel linguaggio tedesco della pubblicità" In: Wolfgang U. Dressler, Corrado Grassi, Rosita R. Schjerve \& Martin Stegu (eds.). Parallela 3. Tübingen: Narr, 159-174.

Gusmani, Roberto. 1981. Saggi sull'interferenza linguistica. Napoli: Liguori.

Harnisch, Rüdiger. 1990. "Die Pluralbildung des Substantivs im Deutschen - Ein Fall von 'Grundformflexion'?' In: Bassarak et al. (eds.), 37-55.

Jørgensen, Mogens Wied. 1980. "Zur Anzahl der Klassen in der deutschen Substantivdeklination." Kopenhagener Beiträge zur Germanistischen Linguistik. Sonderband 1: Festschrift für Gunna Bech. Copenhagen, 228-261.

Klausenburger, Jurgen. 1989. Review Article of Carstairs (1987). Canadian Journal of Linguistics $34.1,45-58$.

Köpcke, Klaus-Michael. 1988. "Schemas in German Plural Formation." Lingua 74, 303-335.

Köpcke, Klaus-Michael. 1993. Schemata bei der deutschen Pluralbildung. Tübingen: Narr.

Korte, Barbara. 1986. "Die Pluralbildung als Paradigma linguistischer Theorien." Deutschunterricht 38.2, $15-30$.

Kühebacher, Egon. 1968. "Deutsch-italienischer Lehnwort-Austausch." In: Walther Mitzka (ed.). Wortgeographie und Gesellschaft. Festgabe für Ludwig E. Schmitt. Berlin: de Gruyter, 488-525.

Mayerthaler, Willi. 1981. Morphologische Natürlichkeit. Wiesbaden: Athenaion

Munske, Horst H. 1983. "Zur Fremdheit und Vertrautheit der 'Fremdwörter' im Deutschen. Eine interferenzlinguistische Skizze." In: D. Peschel (ed.). Germanistik in Erlangen. Erlanger Forschungen Reihe A, Geisteswissenschaften Bd. 31. Erlangen: Universitätsbund, 559-595.

Nyman, Martti. 1987. "Is the Paradigm Economy Principle Relevant?" Journal of Linguistics 23, 251-267.

Öhmann, Emil. 1924. Der s-Plural im Deutschen. Helsinki.

Poitou, Jacques. 1987. "Wie fremd sind Fremdsubstantive im Deutschen? — Eine morphologische Untersuchung." In: Wolfgang U. Wurzel (ed.). Studien zur Morphologie und Phonologie II Linguistische Studien 156, Reihe A. Zentralinstitut für Sprachwissenschaft. Berlin: Akademie der Wissenschaften der DDR, 93-116.

Rettig, Wolfgang. 1972. Sprachsystem und Sprachnorm in der deutschen Substantivflexion. Tübingen: Narr.

Rohlfs, Gerhard. 1969. "Grammatica storica dell'italiano e dei suoi dialetti". Torino: Einaudi.

Tesch, Gerd. 1978. Linguale Interferenz. Theoretische, terminologische, und methodologische Grundfragen zu ihrer Erforschung. Tübingen: Narr.

Volland, Barbara. 1986. Französische Entlehnungen im Deutschen. Transferenz und Integration auf phonologischer, graphematischer und lexikalisch-semantischer Ebene. Tübingen: Niemeyer.
Werner, Otmar. 1969. "Das deutsche Pluralsystem (strukturelle Diachronie)." In: Hugo Mose (ed.). Sprache - Gegenwart und Geschichte. Probleme der Synchronie und Diachronie. Sprache der Gegenwart 5. Düsseldorf, 92-128.

Wurzel, Wolfgang U. 1984. Flexionsmorphologie und Natürlichkeit. studia grammatica XXI. Berlin: Akademie-Verlag.

Wurzel, Wolfgang U. 1987a. "System-dependent Morphological Naturalness in Inflexion." In: Wolfgang U. Dressler, Willi Mayerthaler, Oswald Panagl \& Wolfgang U. Wurzel (eds.). Leitmotifs in Natural Morphology. Amsterdam: Benjamins, 59-96.

Wurzel, Wolfgang U. 1987b. "Grammatische Normen und Sprachveränderung." In: Bärbel Techtmeier (ed.). Theoretische und praktische Fragen der Sprachkultur. Linguistische Studien 170, Reihe A. Berlin: Akademie-Verlag, 145-160.

Wurzel, Wolfgang U. 1988. "Gedanken zur Flexionsklassenmarkiertheit." In: Manfred Bierwisch et al. (eds.). Syntax, Semantik und Lexikon. studia grammatica XXIX. Berlin: Akademie-Verlag, 259-277.

Wurzel, Wolfgang U. 1989. Review Article of Carstairs (1987). In: Geert Booij \& Jaap van Marle (eds.). Yearbook of Morphology. Dordrecht: Foris, 205-227. 